\title{
PRESIDENT'S REPORT FOR VOLUME 53
}

As I take over the presidency from the able hands of Mike Vasey, I am pleased to report that the California Botanical Society continues in good health.

I would like to thank the officers and council members for their continued efforts to keep the Society vibrant and relevant. Every year we all seem to get a little bit busier. So, the commitment of people who find time in their overbooked schedules to build and sustain the Society is all the more laudable.

A primary reason for the continued success of the Society is the quality of our quarterly publication, Madroño. John Hunter, the editor of Madroño, deserves our kudos for the quality of the journal, as do the contributing editors, authors, and reviewers whose concrete efforts embody our mission of advancing Western American botany. This year, a special issue of Madroño appeared with a flora of the liverworts and hornworts of California. This is a companion volume to the two issues on the moss flora published in 2004. This set comprises a complete bryoflora of the state and will be an important reference for decades to come. John Hunter's term as editor extends through 2007, but we are looking for a new editor in order to effect a seamless transition. If you are interested in making a truly lasting contribution to our field, or if you know of an excellent candidate, please contact John Hunter or me regarding the future editorship.

The most significant project of the past year has been preparing for online publication of the journal. Corresponding Secretary Sue Bainbridge, along with Bruce Baldwin and Jim Shevock, spent many hours researching possible approaches and finally recommended that the Society partner with BioOne to make Madroño articles available through an online service. This exciting development, one that we have anticipated for some time, should take place by the publication of the first issue of Madroño next year. Web access to articles will increase the visibility and impact of articles published in Madroño and will increase the frequency of their citation as well. This, in turn, is certain to increase the number of articles submitted for publication, a move that will help maintain the high quality of the journal. Finally, online access will increase the ability of those botanists who work at facilities without extensive libraries to have immediate access to articles This important transition will have somewhat unpredictable effects on the long-term finances of the Society. Although online publication will result in new revenue streams for the Society, many botanical societies have seen a decrease in institutional memberships after going online. This fact, combined with ever-increasing publication costs, will create a challenge to keep membership and subscription affordable. Increasing our endowment is one way that we can continue to provide our members with low cost access to benefits. If you can afford it, please consider giving to the endowment fund while renewing. A contribution to the future of botany is a lasting and worthwhile investment.

Another way to help the Society is by encouraging your colleagues to become members. There is no time like the present to do your part. Incidentally, if you haven't renewed your membership yet, please take the time to do so right now. Timely renewals avoid confusion, added costs, and wear-and-tear on our volunteers.

I encourage everyone to attend the Society's biennial graduate student meeting and annual banquet at the
California Polytechnic University in San Luis Obispo on Saturday February 17, 2007. San Luis Obispo is a charming town and an excellent venue for a meeting. Second VicePresident Matt Ritter will be coordinating this event. At the graduate student meeting, held during the day, students from different institutions will be presenting their research proposals, research-in-progress, or completed research in botany in a standard scientific-meeting format. These meetings are always interesting and provide an excellent opportunity to see the future direction of botanical research. In the evening, at the annual banquet, we will have the great pleasure of hearing Constance Millar, Research Paleoecologist for the USDA Forest Service, speaking on the history of climate change in California. In this period of justified alarm, we will find some comfort in taking a longer view of these issues.

The mission of the Society reaches beyond the political boundaries of California to all of Western America. The Annetta Carter fund was established to provide seed money for plant research in Baja California, Mexico. In 2006, Peter Garcia used funds from the Annetta Carter Fund to make important collections of plant specimens in Baja California. These specimens will contribute to the ongoing Flora of Baja California Project at the San Diego Natural History Museum. If you wish to contribute to the Fund, you can give a line item contribution via the membership form. Another way in which the Society furthers its mission is by occasionally sponsoring important symposia at professional meetings. In June 2006, we sponsored "Ecological Restoration in a Changing World: Case Studies from California", a symposium at the National Society for Conservation Biology meeting in San Jose. Council member Jeff Corbin and then-President Mike Vasey performed all the heavy lifting in arranging this symposium. Look for articles arising from this meeting in future issues of Madroño.

First Vice-President Stephania Mambelli continues to do a great job of assembling a first-rate roster of speakers for our monthly meetings in Berkeley. This year's speakers have included Todd Keeler-Wolf (CDFG), Mark Brunell (U Pacific), Debra Ayres (UC Davis), Radika Bhaskar (Stanford), and Jarmila Pittermann (UC Berkeley). Refreshments are being offered before and after the meetings to facilitate socializing and discussion. Attendance has been high so far. So, if you are not too far away from Berkeley, please come to a meeting or two. I am sure you will enjoy it. Another enjoyable occasion was the annual banquet in February, 2006 in Claremont, California. I would like to thank Second Vice-President Travis Columbus, of the Rancho Santa Ana Botanic Garden, for planning this delightful event. It was enjoyed by all who attended; the banquet speaker, Jon Keeley, talked about his research on fire ecology, a central ecological phenomenon in California.

I also thank Recording Secretary Staci Markos, student representative Vicente Garcia and ex-president Bruce Baldwin for their dedicated commitment and contributions to furthering the goals of the Society, and to all of our members for your continuing support. I wish you all a great year in 2007, as well as a wonderful botanical field season.

DEAN G. KELCH

December, 2006 


\section{$2 \mathrm{BHL}$ Biodiversity Heritage Library}

Kelch, Dean G . 2006. "PRESIDENT'S REPORT FOR VOLUME 53." Madroño; a West American journal of botany 53, 412-412.

https://doi.org/10.3120/0024-9637(2006)53[412:prfv]2.0.co;2.

View This Item Online: https://www.biodiversitylibrary.org/item/185047

DOI: https://doi.org/10.3120/0024-9637(2006)53[412:prfv]2.0.c0;2

Permalink: https://www.biodiversitylibrary.org/partpdf/168990

\section{Holding Institution}

Smithsonian Libraries

\section{Sponsored by}

Biodiversity Heritage Library

\section{Copyright \& Reuse}

Copyright Status: In Copyright. Digitized with the permission of the rights holder License: http://creativecommons.org/licenses/by-nc/3.0/ Rights: https://www.biodiversitylibrary.org/permissions/

This document was created from content at the Biodiversity Heritage Library, the world's largest open access digital library for biodiversity literature and archives. Visit BHL at https://www.biodiversitylibrary.org. 